\title{
Water use and time analysis in ablution from taps
}

\author{
Roubi A. Zaied $^{1,2}$
}

Received: 1 November 2015/Accepted: 28 March 2016/Published online: 12 April 2016

(c) The Author(s) 2016. This article is published with open access at Springerlink.com

\begin{abstract}
There is a lack of water resources and an extreme use of potable water in our Arab region. Ablution from taps was studied since it is a repeated daily activity that consumes more water. Five different tap types are investigated for water consumption fashions including traditional mixing tap and automatic tap. Analyzing 100 experimental observations revealed that $22.7-28.8 \%$ of ablution water is used for washing of feet and the largest water waste occurs during washing of face portions. Moreover, 30-47 \% amount of water consumed in ablution from taps is wasted which can be saved if tap releases water only at moments of need. The push-type tap is being spread recently especially in airports. If it is intended for use in ablution facilities, batch duration and volume must be tuned. When each batch is $0.25 \mathrm{~L}$ of water and lasts for $3 \mathrm{~s}, 3 \mathrm{~L}$ are sufficient for one complete ablution in average which means considerable saving. A cost-benefit model is proposed for using different tap types and an economic feasibility study is performed on a case study. This analysis can help us to design better ablution systems.
\end{abstract}

Keywords Ablution action times - Ablution water . Push-type tap - Tap water costs $\cdot$ Knee operated tap

Roubi A. Zaied

roubi.zaied@gmail.com; rouby.nasr@bhit.bu.edu.eg; roubi.zaied@nbu.edu.sa

1 Department of Mechanical Engineering, Faculty of Engineering, Benha University, Benha, Egypt

2 Department of Industrial Engineering, Faculty of Engineering, Northern Border University, Arar, Saudi Arabia

\section{Introduction}

Water is the basis of life and it is our duty to save water and develop water resources. Ablution is a mandatory religious routine for Muslims that is repeated several times daily for prayers and other deeds. Ablution actions typically include washing of hands, face, mouth, nose, arms, swabbing on head, ears and feet. Conservation of water is a religious and national obligation especially with the lack of water resources. The rate of water consumption in the Kingdom of Saudi Arabia (KSA) is one of the highest rates in the world despite the fact that it is one of the poorest areas in sweet water resources.

In ablution process, the tap is usually left running, much good water is wasted in the process (Suratkon et al. 2014). It can be said that about half of the tap water flows directly to the drain without any contamination (Al Mamun et al. 2014).

Tracking of water consumption patterns in ablution and washing is reached in some public and private facilities in multiple regions in the KSA. The most important observation confirmed by the researcher are:

- Handle taps consume extra amount of water during the moments of opening and closing because of using hands in turning the tap handles. Thus, cannot benefit of flowing water. Ghanem (2008) confirmed that using slow closure mixer taps wastes about $30 \%$ of the amount of water consumed.

- Mixer taps that mix hot and cold water consume more water every time of use at the start of opening because the user leaves the water flowing until its temperature reaches a suitable level.

- Mechanical push-button taps waste water because the amount of water in each batch (sometimes more than $1 \mathrm{~L}$ ) is frequently more than the user need.

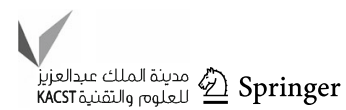


- Electronic taps are expensive and need electrical power and means of protection to isolate the wiring. Further, they have a time lag between the moment of cutting the beam and the onset of water flow and other time lag before it shuts down automatically.

The amount that was used by the Holy Prophet Muhammad prayer and peace be upon him (PPBUH) for the performance of ablution is one full palms. The islamic historical records indicated that Prophet Mohammad [peace be upon him] used to make ablution using one "Mudd" of water [Hadith from Bukhari and Muslim] which is equivalent to about $0.544 \mathrm{~L}$ of water (Al Mamun et al. (2014). Others prove slightly higher evaluations but, anyhow the correct amount is less than $1 \mathrm{~L}$.

At present, Muslims consume more water in their ablutions and previous studies showed different evaluations of the average amount of ablution water used. Abu Rozaiza (2002a) measured the amount of water used in ablution in nearly 40 Masjids and in the two holy Masjids, and found it 3-7 L per person at a time. In his other study, Abu Rozaiza (2002b) determined the average ablution water amount as 2.5-4.5 L/individual in some masjids, schools and governmental buldings. But he found that this amount increases to $5 \mathrm{~L}$ in the two holy Harams and 6-7.5 L/individual in A'rafah and Muzdalifah in Hajj days.

In his project named "the islamic bathroom", Mohamed Ben-Ghalbon estimated average water amount consumed by an average Muslim in ablution as $10 \mathrm{~L}$ in the Gulf region and the Middle East. However, he confirms that same amount that was used by the PPBUH is one full palms (688 $\mathrm{mL}$ approximately) and it is sufficient. He proposed installation of a metal pot with a capacity of $688 \mathrm{~mL}$ beside the ablution basin. He had patent grants for this idea coded DE60232314D1, EP1372448A1 and WO2002071905A1. He supposes that the use of this low cost product will combat the waste of potable water and will be available for the majority of the Islamic world citizens other than the use of costly electronic taps. But the practical reality testifies that this idea is not popular yet.

Besari et al. (2009) built an automatic ablution machine using camera as sensor and servomotor as an actuator. They stated that, by testing this machine, it will save 1-7 L during ablution. Their experiments revealed that manual ablution consumes about 2-9 L/individual in about $40-80 \mathrm{~s}$ of time where using their automatic ablution machine decreased water consumption to about 2-3 L/individual in about 55-70 s.

Al-Mughalles et al. (2012) studied water quantity consumed by one worshipper during the ablution in two masjids in Sana'a. They determined the average greywater quantity produced by one worshipper as 2.7 L. Johari et al. (2013a, b) stated that ablution process normally requires about 6-9 L of water volume, but according to Islamic hadiths, about half to two liters only will be used for ablution. Suratkon et al. (2014) conducted a study to develop and verify a conceptual model of the ablution water recycling system, named SmartWUDHU'. They considered the average volume of water required for a single ablution ritual as $5.0 \mathrm{~L}$, obtained by monitoring a number of users at various prayer times in a day.

In summary, PPBUH was using less than $1 \mathrm{~L}$ of water for his ablution while Muslims nowadays use 2-10 L. In this study, the researcher experimentally analyzes action and water use times in ablution from some tap types. A mathematical model is proposed for economic feasibility of using different taps. This analysis can help better design of ablution systems.

\section{Methodology}

Experiments have been conducted on a group of mature Muslim males in order to identify real consumption of water in ablution. Experiments were carried out in the KSA in spring and fall seasons of 2014 where single source of water is used so no time is consumed in tuning of water temperature. The participants are told that their ablution processes is being video recorded and emphasized to behave in quite natural mode. More than 100 experiments are conducted for ablution from 5 different tap types (Taps' Images and specifications are shown in Table 1) and 100 good cases are considered for analysis after excluding imperfect recording cases. Each ablution case is video recorded at 30 frames/s. Through analysis of videos using Windows Movie Maker, at playback resolution of $0.03 \mathrm{~s}$, each video is dissected into two groups; water contact clips and water free running clips. The total time of each group is computed for each case and then statistical calculations are performed. Table 2 summarizes the obtained results. Tables 3 and 4 and Figs. 1 and 2 present time distribution in the two extreme cases. Shaded table rows indicate times of positive-water-use while unshaded rows indicate times of water wasting. In the two figures, time periods of water usage are on left side and times of water wasting are on right side. To quantify the water consumption, a flowmeter of $0.01 \mathrm{~L}$ resolution is installed at the supply of the mechanical knob tap and $1.0 \mathrm{~L}$ resolution-flowmeters are installed at the supplies of the single lever mixing taps and the automatic tap.

The push-type tap is given more interest as it is being spread recently especially in airports. This tap is intended to be durable to have minimum repair unlike the turning handle taps which need repeated repair because of mechanical wear that leads to water leakage. Its source 
Table 1 Tap types used in ablution cases in this study

\begin{tabular}{|c|c|c|c|c|c|c|}
\hline & Valve image & Description & Advantages & Disadvantages & Location & $\begin{array}{l}\text { Number of } \\
\text { observations }\end{array}$ \\
\hline 1 & & $\begin{array}{l}\text { Two mechanical knobs } \\
\text { open and close the tap in } \\
\text { several revolutions } \\
\text { Flow rate is up to } 20 \mathrm{~L} / \mathrm{min}\end{array}$ & More common & $\begin{array}{l}\text { In ablution, it necessitate } \\
\text { user bowing because of } \\
\text { low elevation and vertical } \\
\text { pathway of water stream } \\
\text { Not durable }\end{array}$ & $\begin{array}{l}\text { A WC in old west } \\
\text { building of faculty of } \\
\text { engineering, Al } \\
\text { Muhammadiyah, Arar, } \\
\text { Northern Border } \\
\text { University (NBU), } \\
\text { KSA }\end{array}$ & 30 \\
\hline \multirow[t]{2}{*}{2} & & $\begin{array}{l}\text { Mixing short neck-tap with } \\
\text { single lever to control } \\
\text { water flow and } \\
\text { temperature }\end{array}$ & $\begin{array}{l}\text { Comfort and } \\
\text { quick open } \\
\text { and close }\end{array}$ & $\begin{array}{l}\text { Not suitable for ablution } \\
\text { (washing of arms and legs) } \\
\text { since its short neck and } \\
\text { vertical direction of water } \\
\text { stream necessitate user } \\
\text { bowing }\end{array}$ & \multirow[t]{2}{*}{$\begin{array}{l}\text { A WC in third floor, } \\
\text { faculty of science } \\
\text { building, new NBU } \\
\text { campus, Arar, KSA }\end{array}$} & \multirow[t]{2}{*}{13} \\
\hline & & $\begin{array}{l}\text { Full opening water flow rate } \\
\text { is up to } 10 \mathrm{~L} / \mathrm{min}\end{array}$ & $\begin{array}{l}\text { Sole control of } \\
\text { water flow } \\
\text { rate and } \\
\text { temperature }\end{array}$ & Manual open and close & & \\
\hline \multirow[t]{2}{*}{3} & & $\begin{array}{l}\text { Mixing high neck-tap with } \\
\text { single lever to control } \\
\text { water flow and } \\
\text { temperature }\end{array}$ & $\begin{array}{l}\text { Comfort use of } \\
\text { water stream } \\
\text { and quick } \\
\text { open and } \\
\text { close }\end{array}$ & $\begin{array}{l}\text { The majority of users do not } \\
\text { close it while hands are } \\
\text { busy in cleaning or } \\
\text { through switching between } \\
\text { ablution organs }\end{array}$ & \multirow[t]{2}{*}{$\begin{array}{l}\text { A WC in third floor, } \\
\text { faculty of science } \\
\text { building, new NBU } \\
\text { campus, Arar, KSA }\end{array}$} & \multirow[t]{2}{*}{23} \\
\hline & & $\begin{array}{l}\text { Full opening water flow rate } \\
\text { is up to } 10 \mathrm{~L} / \mathrm{min}\end{array}$ & $\begin{array}{l}\text { Sole control of } \\
\text { water flow } \\
\text { rate and } \\
\text { temperature }\end{array}$ & Manual open and close & & \\
\hline 4 & & $\begin{array}{l}\text { Pushtype; a terminal push } \\
\text { button opens the tap } \\
\text { when depressed; water } \\
\text { flow continues for 7-15 s } \\
\text { and then shuts off } \\
\text { automatically }\end{array}$ & $\begin{array}{l}\text { Quick open } \\
\text { and } \\
\text { automatic } \\
\text { close } \\
\text { depending } \\
\text { on viscous } \\
\text { elastic } \\
\text { damping }\end{array}$ & $\begin{array}{l}\text { Uses single water source; } \\
\text { does not mix hot and cold } \\
\text { water } \\
\text { User cannot synchronize its } \\
\text { batches in ablution } \\
\text { sequence } \\
\text { Wastes water; gives about } \\
1.0 \mathrm{~L} \text { of water per batch }\end{array}$ & $\begin{array}{l}\text { An ablution facility in } \\
\text { ground floor, faculty } \\
\text { of science building, } \\
\text { new NBU campus, } \\
\text { Arar, KSA }\end{array}$ & 15 \\
\hline 5 & & $\begin{array}{l}\text { Electronic tap opens when } \\
\text { hands cut infrared rays } \\
\text { Full opening water flow rate } \\
\text { is up to } 5 \mathrm{~L} / \mathrm{min} \text { ) }\end{array}$ & $\begin{array}{l}\text { Automatic } \\
\text { open and } \\
\text { close }\end{array}$ & $\begin{array}{l}\text { Needs electrical energy } \\
\text { More expensive } \\
\text { Sometimes it is difficult to } \\
\text { determine the } \\
\text { suitable position for hands } \\
\text { to cut the ray }\end{array}$ & $\begin{array}{l}\text { A WC in third floor, } \\
\text { faculty of science } \\
\text { building, new NBU } \\
\text { campus, Arar, KSA }\end{array}$ & 19 \\
\hline
\end{tabular}

water needs to be preconditioned as it does not mix hot and cold water itself. A total of 40 taps were checked for batch volumes and durations in different places [ten in public water cycles (WCs) of local departure hall in Jeddah airport, ten in new ablution facility in Haram of Makkah and 20 in faculty of science building, ground floor, new NBU campus, Arar, KSA].

\section{Experimental results and discussion}

Regarding the analyzed 100 cases, the total time used in ablution is 33-109.5 s and the amount of water used from all tap types is $0.65-7.33 \mathrm{~L}$. The average total ablution time from the different five tap types may be affected by their flowrate and design though all taps have sprayers at 
Table 2 Times spent and water used in ablution from the mechanical knobs tap

\begin{tabular}{|c|c|c|c|c|}
\hline \multicolumn{2}{|l|}{ Actions of Ablution } & Minimum & Maximum & Average \\
\hline \multicolumn{2}{|c|}{ Opening of water tap and moving palms to water stream } & 0.5 & 2.6 & 1.2 \\
\hline \multicolumn{2}{|c|}{ Washing of hands and collecting water in palms for washing of mouth and nose } & 3.2 & 17.6 & 7.6 \\
\hline \multicolumn{2}{|c|}{ Washings of mouth and nose cavity, and moving palms to water stream } & 2.3 & 19.1 & 7.6 \\
\hline \multicolumn{2}{|r|}{ Collecting water in palms for face wash } & 1.2 & 11.0 & 3.2 \\
\hline \multicolumn{2}{|c|}{ Moving palms to water stream, washings of face and bringing arms under water stream } & 2.2 & 17.9 & 6.6 \\
\hline \multicolumn{2}{|c|}{ Washing of arms, collecting water in palms for swabbing on head and cleaning of ears } & 2.6 & 15.8 & 7.2 \\
\hline \multicolumn{2}{|c|}{ Swabbing on head, cleaning of ears and moving palms and legs to water stream } & 0.0 & 17.1 & 7.4 \\
\hline \multicolumn{2}{|r|}{ Washings of legs } & 4.8 & 29.5 & 13.6 \\
\hline \multicolumn{2}{|c|}{ Taking legs away from water stream and closing of water tap } & 2.8 & 8.0 & 5.6 \\
\hline \multirow{5}{*}{ Total amounts } & Total time that tap maintains open (Seconds) & 33.1 & 109.5 & 59.9 \\
\hline & Actual total time of using water in ablution (Seconds) & 16.6 & 66.8 & 31.5 \\
\hline & Total time that water is running without use (Seconds) & 10.5 & 49.2 & 28.4 \\
\hline & Total amount of water used in ablution (Liters) & 0.65 & 7.33 & 3.99 \\
\hline & Percentage of tap water wasted during ablution from the tap & & & $47 \%$ \\
\hline
\end{tabular}

Table 3 Times spent and water used in ablution from the automatic tap

\begin{tabular}{|c|c|c|c|c|}
\hline \multicolumn{2}{|l|}{ Actions of Ablution } & Minimum & Maximum & Average \\
\hline \multicolumn{2}{|c|}{ Moving palms under tap waiting for water stream (No water flows) } & 1.2 & 2.1 & 1.5 \\
\hline \multicolumn{2}{|c|}{ Washing of hands and collecting water in palms for washing of mouth and nose } & 4.1 & 5.7 & 4.63 \\
\hline \multicolumn{2}{|c|}{ Washings of mouth and nose cavity, and moving palms to water stream } & 3 & 4.2 & 3.3 \\
\hline \multicolumn{2}{|r|}{ Collecting water in palms for face wash } & 5.8 & 7.3 & 6.72 \\
\hline \multicolumn{2}{|c|}{ Moving palms to water stream, washings of face and bringing arms under water stream } & 2.2 & 16.7 & 6.5 \\
\hline \multicolumn{2}{|c|}{ Washing of arms, collecting water in palms for swabbing on head and cleaning of ears } & 7.1 & 8.5 & 7.6 \\
\hline \multicolumn{2}{|c|}{ Swabbing on head, cleaning of ears and moving palms and legs to water stream } & 3.6 & 6.6 & 4.0 \\
\hline \multicolumn{2}{|r|}{ Washings of legs } & 10.1 & 19.2 & 13 \\
\hline \multicolumn{2}{|c|}{ Taking legs away from water stream and stopping of tap water } & 0.0 & 0.6 & 0.1 \\
\hline \multirow{5}{*}{ Total amounts } & Total time that tap maintains open (Seconds) & 33 & 69 & 45.85 \\
\hline & Actual total time of using water in ablution (Seconds) & 18 & 47 & 32 \\
\hline & Total time that water is running without use (Seconds) & 8 & 24 & 13.9 \\
\hline & Total amount of water used in ablution (Liters) & 1 & 3 & 2 \\
\hline & Percentage of tap water wasted during ablution from the tap & & & $30.3 \%$ \\
\hline
\end{tabular}


Table 4 Times spent and water used in ablution from the different taps

\begin{tabular}{lll}
\hline Tap type & $\begin{array}{l}\text { Average total } \\
\text { ablution time (s) }\end{array}$ & $\begin{array}{l}\text { Percentage of } \\
\text { wasted water (\%) }\end{array}$ \\
\hline Mechanical knobs-tap & 59.9 & 47 \\
Mixing short neck-tap & 57.2 & 42 \\
Mixing high neck-tap & 42.8 & 38 \\
Mechanical push button tap & 49.8 & 37 \\
Automatic tap & 49.4 & 30.3 \\
\hline
\end{tabular}

their exits to enlarge the water stream area. As expected, the mechanical knobs tap and the mixing short neck-tap had longest time because of their uncomfortable design while, the mixing high neck-tap shows shortest time because of its comfortable design. The relatively long time for the automatic tap may be related to its low water flowrate. The largest water amount is used in feet washings and the largest water amount is wasted during washings of face and bringing arms under water stream. The Mechanical knob tap is the worst in wasting (47 \%) and automatic tap wastes considerable amount of water because of its time delay though it has minimum water wastage $(30.3 \%)$. This means that about $30.3-47 \%$ of the amount of water consumed in ablution from a these taps can be saved if tap releases water only at moments of need.
Regarding the push-type tap, it was found that amount of water released each batch is $0.46-1.1 \mathrm{~L}$ with an average of $0.78 \mathrm{~L}$ and the batch duration is $5-11 \mathrm{~s}$ with an average of $8 \mathrm{~s}$. The average water batch released a time is more than the amount that was used by the Holy Prophet. In average, user needs five batches for his ablution. Based on these results and data in Tables, for best design; batch time must be decreased. For example, if each batch lasts for $3 \mathrm{~s}$, the four water-positive-use ablution steps can be performed with a total of 12 batches (two batches for hands, three for face, three for arms and four for legs). At water flowrate of $5 \mathrm{~L} / \mathrm{min}(0.25 \mathrm{~L} / \mathrm{batch}), 3 \mathrm{~L}$ are sufficient for one complete ablution which means considerable saving.

Solving the problem of excess water consumption can be achieved technically through good tap control design or recycling disposed greywater. Johari et al. (2013a, b) concluded that in order to reduce water usage while practicing ablution, introduce new design for ablution tub system. Al Mamun et al. (2014) assume that ablution water wastage can be avoided by using water from a container or pail. Experience from overseas, and in particular in arid and semi-arid countries, indicates that greywater can be a cost effective alternative source of water (Prathapar et al. 2006). Al Arni (2014) reported some suggestions for the solution of water crisis on the long term by using sandfilters and biosandfilters in masjids and homes after separation of graywater from blackwater.

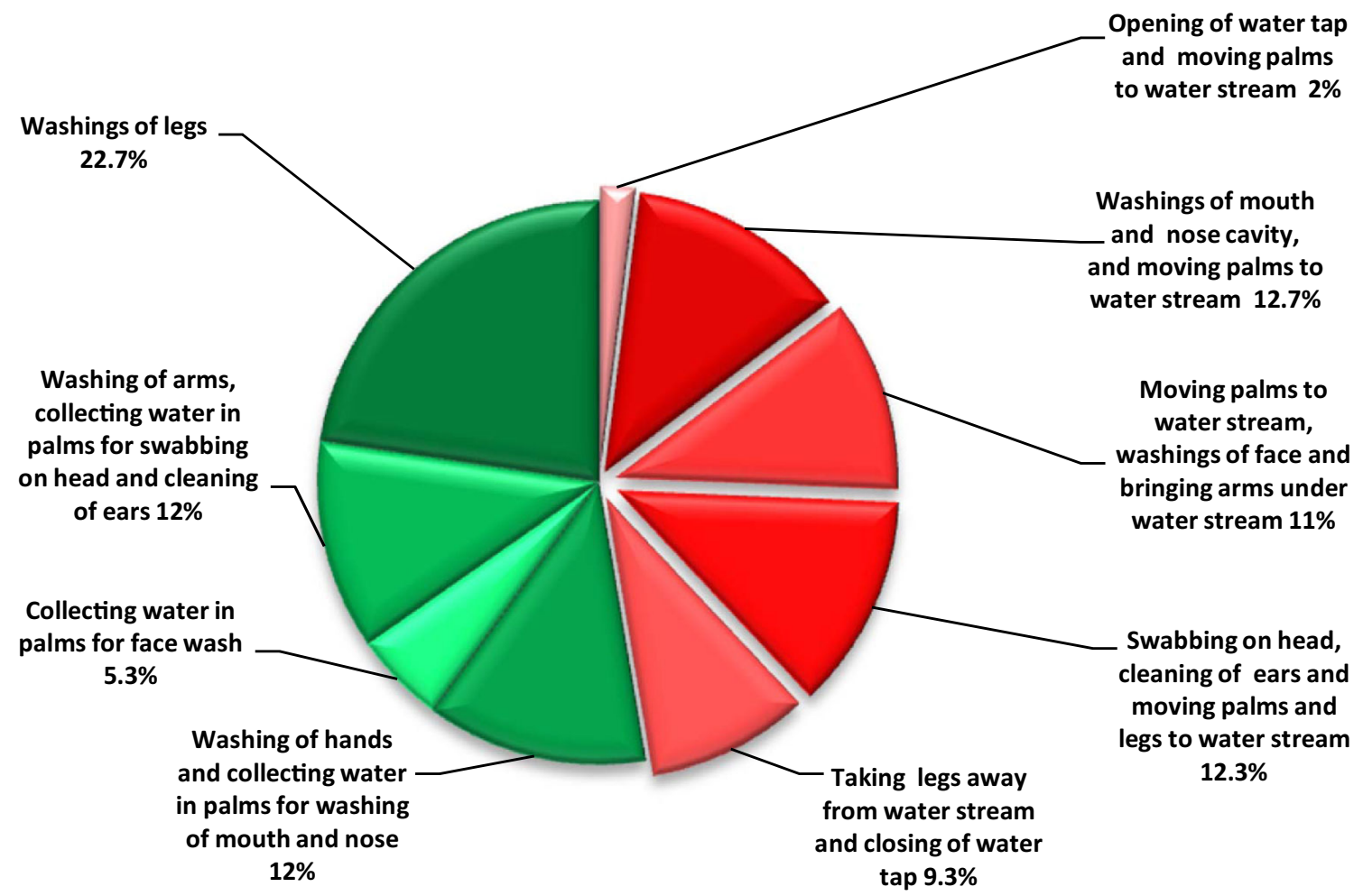

Fig. 1 Average time distribution in ablution from slow opening knob tap 


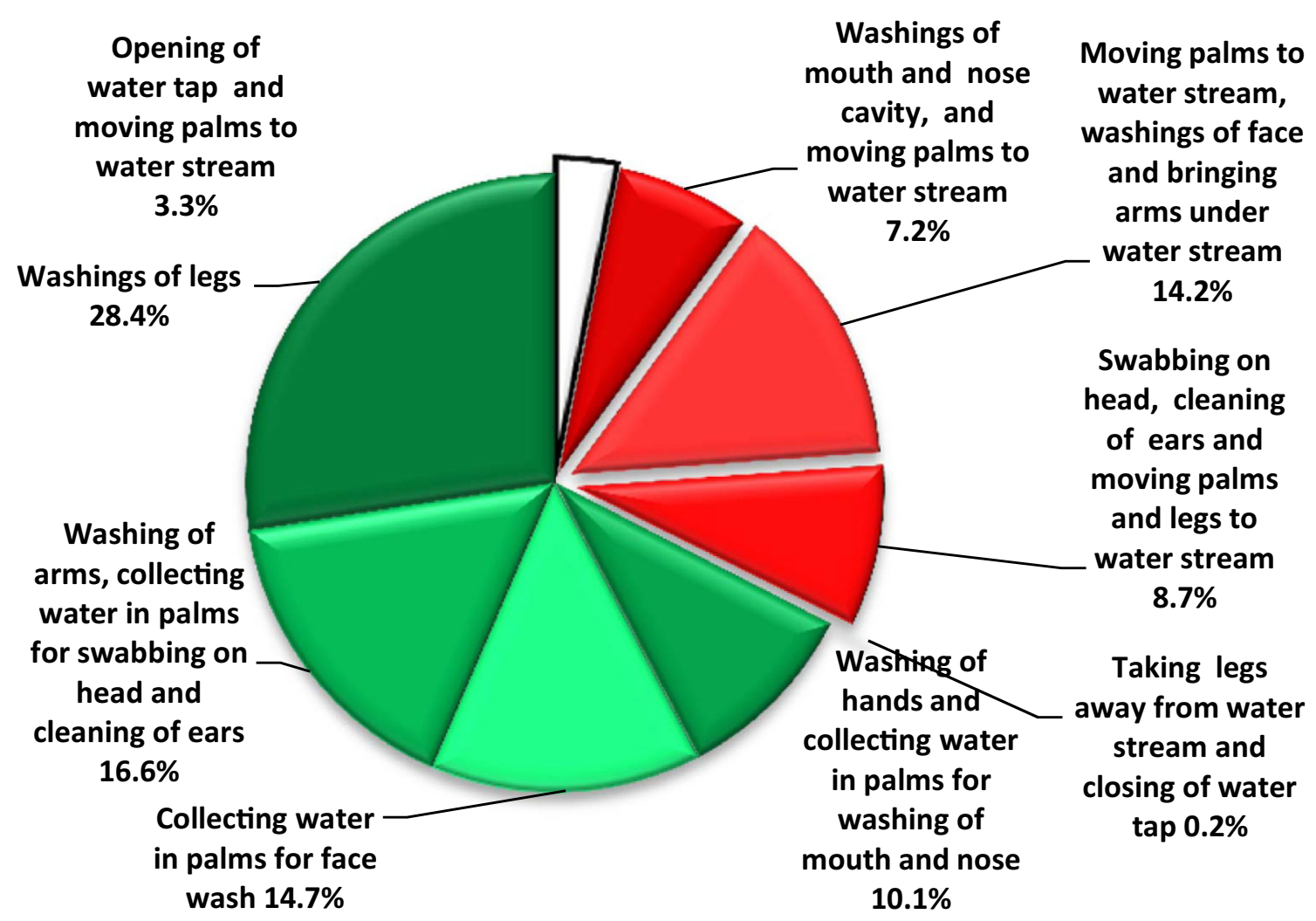

Fig. 2 Average time distribution in ablution from the automatic tap

Recycling of greywater is a good treatment of potable water wasting problem but, it is better to make prevention. Commercially, some automatic ablution machines are available but they need high capital, running and maintenance costs. It is important to manufacture good look water saving taps with reasonable price. The tap design affects the water consumption fashions, thus a good tap deign can greatly help the user to save more water. It is proposed to use legs (feet or knees) instead of hands in opening taps to help decreasing water waste. A system is to be developed in a manner that facilitates its practical application to already installed water taps without need to replace them entirely.

\section{An estimation of economic feasibility of using a specific sort of taps}

A "tap" in the British English is used for any everyday type of valve, particularly the fittings that control water supply to bathtubs and sinks and "faucet" is the most common term in the US. There are several types of taps or faucets differ in shapes, durability, and appearance, opening mechanism, water flow rates, sizes and prices which vary accordingly. Some people prefer good look over other factors in selecting water taps. Ghanem (2008) states that practical application showed that if the price per cubic meter is estimated as five riyals, the value of what was saved from the water in just 4 days is equivalent to the value of rationalization tools (SR 385) that have been installed in one Masjid.

Here it is tried to investigate which type of taps is economically better in water saving as water saving taps are generally more expensive.

The total water supply cost from a tap, per month, can be modeled as follows:

$T_{\mathrm{c}}=W_{\mathrm{c}}+D_{\mathrm{c}}+R_{\mathrm{c}}+M_{\mathrm{c}}$,

where $T_{\mathrm{c}}$ monthly total water supply cost from a tap, $W_{\mathrm{c}}$ monthly water supply price, $D_{\mathrm{c}}$ monthly tap deterioration cost (installation cost divided by its useful life in months), $R_{\mathrm{c}}$ monthly tap running cost (e.g. energy for automatic taps), $M_{\mathrm{c}}$ tap monthly maintenance cost.

Change in monthly cost when replacing the tap:

$\Delta T_{\mathrm{c}}=T_{\mathrm{cN}}-T_{\mathrm{cO}}$,

where $T_{\mathrm{cN}}$ and $T_{\mathrm{cO}}$ are the total water supply costs for the new and old tap, respectively.

A tap is considered feasible if the cost of water saved by it surpasses its installation, running and maintenance costs during its useful life. Abu Rozaiza (2002a, b) stated that the price of water that being sold in movable containers in 
KAS is $10-50 \mathrm{SR} / \mathrm{m}^{3}$. Alternatively, Ouda (2013) states that the water tankers price is on average SAR $6 / \mathrm{m}^{3}$. Practically, for the end user in KSA, this cost depends on the raw water source and the water treating system.

\section{A case study}

The proposed economic feasibility model could be applied on some taps of washing basins in a public facility. Field data showed that in average a traditional washing tap passes $5 \mathrm{~m}^{3}$ of water monthly which cost in average SR 100 (the price in this area is $120 \mathrm{SR}$ per $6 \mathrm{~m}^{3}$ movable containers), If these taps are replaced by automatic taps instead and the water cost decreased by $15 \%$, according to Eq. (1), the monthly total water supply cost from an automatic tap can be calculated as follows:

$W_{\mathrm{c}}:$ water price $=(100) \times(0.85)=\mathrm{SR} 85$ monthly.

Assuming the automatic tap price in addition to its installation cost is SR 600 and its useful life is 60 months, then,

$D_{\mathrm{c}}($ tap deterioration cost $)=600 / 60=$ SR 10 monthly, whereas traditional tap installation cost is only SR 60 and its useful life is 60 months as well so, its monthly deterioration cost is only SR1.

$R_{\mathrm{c}}$ (tap running cost) $=\mathrm{SR} 2$ monthly for changing batteries.

$M_{\mathrm{c}}$ tap maintenance cost is decreased by SR 10 monthly, thus, total monthly water supply cost change of the automatic tap is:

$$
\begin{aligned}
\Delta T_{\mathrm{c}} & =T_{\mathrm{cN}}-T_{\mathrm{cO}} \\
& =(85+10+2+0)-(100+1+0+10)=-14 .
\end{aligned}
$$

Thus, an automatic tap is considered feasible as it saves SR 14 monthly.

\section{Conclusions}

Through the literature survey and experimental work, it was found that:

- Tap design affects water use pattern in ablution and 100 observation of ablution from five tap types revealed that $30.3-47 \%$ of water consumed in ablution can be saved if tap releases water only at moments of need.

- Analyzing ablution times revealed that largest water amount is used in feet washing and largest water amount is wasted during washings of face.

- If push-type tap is intended for use in ablution facilities, batch duration and volume must be tuned. If each batch of $0.25 \mathrm{~L}$ of water lasts for $3 \mathrm{~s}, 3 \mathrm{~L}$ in average are sufficient for one complete ablution which means considerable saving.

- A model is proposed to estimate the economic feasibility of using a specific sort of taps and it is applied to taps of washing basins in a public facility.

\section{Recommendations and future work}

- Muslims can be motivated for economy of ablution water by reminding them to follow their supreme exemplar who is the PPBUH.

- For using of the push-type tap in ablution facilities, more studies are required to determine the optimal batch duration and volume for maximum saving.

- It is proposed to use legs in opening of ablution taps mechanically to save costs of power and components of alternative electronic ablution machines. A proposed knee operated tap system is currently under development by the researcher.

Acknowledgments Praise is due to Allah for his grace to complete this research. Then, thanks to the University of Northern Border for sponsoring the research; especially the Deanship of Scientific Research. Thanks to every one of my family and my friends who supported me to complete it. Thanks also to the branch of Saudi Ministry of water in Arar for their valuable tools and support. Finally, great thanks to the reviewers of AWS journal for their patience and their wonderful and useful directions. I hope from Allah that the results of this research promise and benefit everyone.

Open Access This article is distributed under the terms of the Creative Commons Attribution 4.0 International License (http:// creativecommons.org/licenses/by/4.0/), which permits unrestricted use, distribution, and reproduction in any medium, provided you give appropriate credit to the original author(s) and the source, provide a link to the Creative Commons license, and indicate if changes were made.

\section{References}

Abu Rozaiza OS (2002a) The concept of rationalization: the causes of failure and success factors. J King Abdul Aziz Univer Eng Sci 14(1):3-57

Abu Rozaiza OS (2002b) Ablution water: prospects for reuse in flushing of toilets at mosques, schools, and offices in Saudi Arabia. J King Abdul Aziz Univer Eng Sci 14(2):3-28

Al Arni S (2014) Treatment and recycling of water resulting from the ablution and homes for help in solution of the water crisis in most countries of Islamic world. J King Saud Univ (in press 6/2013)

Al Mamun A, Muyibi SA, Razak A, Asilah N (2014) Treatment of used ablution water from IIUM masjid for reuse. Adv Environ Biol 8(3):558-564 (special 2014)

Al-Mughalles MH, Abdul Rahman R, Suja FB, Abdullah SMS (2012) Mosque greywater quantity in Sana'a, Yemen. Electron $\mathrm{J}$ 
Geotech Eng 17(Bund k):1593-1603. http://www.ejge.com/ 2012/Ppr12.130e.pdf

Besari ARM, Zamri R, Yusaeri A, Palil MDM, Prabuwono AS (2009) Automatic ablution machine using vision sensor. IEEE symposium on industrial electronics and applications (ISEA 2009), Kula Lumpur, pp 506-509

Ghanem HY (2008) Our role in water conservation. Magazine of waters. http://almyah.net $/ \mathrm{mag} /$ articles.php?action=show\&id=34

Johari NH, Anwar R, Hassan OH, Kamaruzaman MF (2013) Human behaviors influence framework of the ablution tub design. IEEE Business Engineering and Industrial Applications Colloquium (BEIAC)
Johari NH, Hassan OH, Anwar R, Kamaruzaman MF (2013b) A behaviour study on ablution ritual among Muslim in Malaysia. Proc Soc Behav Sci. doi:10.1016/j.sbspro.2013.12.002

Ouda OKM (2013) Review of Saudi Arabia municipal water tariff. World Environ 3(2):66-70. doi:10.5923/j.env.20130302.05

Prathapar SA, Ahmed M, Al Adawi S, Al Sidiari S (2006) Design construction and evaluation of an ablution water treatment unit in Oman: a case study. Int J Environ Stud. doi:10.1080/ 00207230600773257

Suratkon A, Chee MC, Ab Rahman TST (2014) SmartWUDHU: recycling ablution water for sustainable living in Malaysia. J Sustain Dev 7(6):150-157. doi:10.5539/jsd.v7n6p150 